\title{
Ler e escrever criativamente: cores poéticas na prática de letramento literário cadáver esquisito
}

Reading and writing creatively: poetic colors in the practice of literary literacy exquisite corpse

Beatriz Pereira de Almeida

Universidade Federal da Paraíba - UFPB - Paraíba - Brasil

\section{Alinne de Morais Oliveira Cordeiro}

Universidade Federal da Paraíba - UFPB - Paraíba - Brasil

Rildo Cosson

Universidade Federal da Paraíba - UFPB - Paraíba - Brasil

\begin{abstract}
$\longrightarrow$
Resumo: O artigo relata uma prática de letramento literário inspirada na técnica surrealista do cadáver esquisito, vivenciada com alunos do Programa de PósGraduação em Letras da Universidade Federal da Paraíba, no primeiro semestre de 2020. Partindo da presença necessária da poesia na escola (Pinheiro, 2018), a prática se apresenta como uma estratégia didática que pode proporcionar ao educando uma experiência literária dessacralizadora da leitura e da produção poética. Amparados nos pressupostos do letramento literário (Cosson, 2019), discutiremos e analisaremos a experiência de ler e produzir poemas em sala de aula através da técnica do cadáver esquisito. Por meio dessa reflexão analítica, propomos essa prática como uma alternativa aos educadores que, em meio à pandemia da Covid-19, precisam atuar no ensino a distância. Em relação à metodologia, este estudo segue uma abordagem qualitativa de natureza aplicada, quanto aos procedimentos ela se configura como um educational design experiment.
\end{abstract}

Palavras-chave: Cadáver esquisito. Letramento literário. Ensino de literature.

Abstract: The article reports a literary literacy practice inspired by the surrealistic technique of the 'exquisite corpse', experienced with students of the Postgraduate Program in Letters at the Federal University of Paraíba in the first school term of 2020. Starting from the necessary presence of poetry in school (Pinheiro, 2018), the practice is revealed as a didactic strategy that can provide the student with a literary experience that desacralizes reading and poetic production. Based on the assumptions of literary literacy (Cosson, 2019), we will discuss and analyze the experience of reading and producing poems in the classroom throughout the technique of the 'exquisite corpse'. Using this analytical reflection, we propose this practice as an alternative to educators who, in the midst of the Covid-19 pandemic, need to work in distance learning. Regarding the methodology, this study follows a qualitative approach of an applied nature and it is configured as an educational design experiment for the procedures.

Keywords: Exquisite corpse. Literary literacy. Poetic writing. Literature teaching. 


\section{Introdução}

Escrever um texto literário em ambiente escolar pode ser fonte de inseguranças e travamentos, em especial quando se lida com poesia, que parece concentrar, por excelência, todos os estereótipos frequentemente associados à escrita literária, como inspiração, hermetismo, uso criativo e requintado da língua. Por essa razão, investir em práticas de letramento literário que quebrem as crenças de que a produção de um poema requer procedimentos, dons e saberes especiais pode abrir caminhos para uma relação mais leve e prazerosa com a leitura e escrita literária.

Este estudo tem como objetivo relatar uma prática de letramento literário que envolve a escrita de poemas em sala de aula. Trata-se, como veremos adiante, da adaptação de uma técnica surrealista intitulada "cadáver esquisito". A prática foi vivenciada no primeiro semestre de 2020, como parte das atividades de uma disciplina do Programa de PósGraduação em Letras da Universidade Federal da Paraíba. Inicialmente, foi planejada para ser desenvolvida na forma de ensino presencial, mas, em decorrência da pandemia do novo coronavírus, os planos foram alterados e as etapas que constituem o processo adaptadas para o meio virtual, com encontros em plataforma de comunicação a distância.

Apesar de ter sido ministrada a alunos graduados, a prática foi pensada para ser experienciada com uma turma do nono ano do ensino fundamental. Acreditamos que os resultados obtidos através da atividade a configuram como uma alternativa válida e positiva para muitos professores que lidam com o ensino de literatura e são expostos aos desafios que envolvem a leitura e a escrita de textos literários, principalmente em um contexto de pandemia.

Em termos metodológicos, este artigo é um relato de experiência de cunho qualitativo, direcionado à uma análise da aplicação de uma prática de letramento literário, ao modo de um educational design experiment (PLOMP \& NIEVEEN, 2013; SEEL, 2012). Ele está dividido em quatro partes. Na primeira, temos os antecedentes contextuais e históricos do cadáver esquisito, em que abordaremos alguns conceitos e informações sobre a técnica para os surrealistas, bem como seu surgimento. Ainda neste tópico, haverá a inserção dos pressupostos teóricos correlatos à prática vivenciada, como o letramento literário e a poesia em sala de aula. Na segunda, descreveremos a prática aplicada, apresentando uma análise do poema trabalhado com os alunos e as etapas que constituem a prática. Em um terceiro momento, analisaremos a prática literária a partir das produções dos alunos envolvidos e de suas reações. Por fim, teremos as considerações finais, nas quais fazemos uma reflexão sobre a consistência e coerência da prática em relação ao letramento literário.

\section{Conceitos operacionais}

\subsection{O cadáver esquisito dos surrealistas}

A técnica do cadáver esquisito foi um procedimento de escrita literária proposta pelos surrealistas, sob o contexto de um mundo colapsado e entreguerras, em meados de 1920. O movimento surrealista buscava se esquivar do racionalismo e da supremacia do consciente sob o universo onírico e oculto da psiquê humana, indo de encontro à objetividade a que os homens e as coisas pareciam estar afeitos até então. Nesse sentido, há um movimento para que o indivíduo se volte para o seu interior, já que lá habitam suas fantasias, desejos e libertações, o que faz a psicanálise se constituir em um dos pilares do Surrealismo. Apenas o inconsciente, de acordo com a vanguarda, reserva e poderá revelar quem verdadeiramente somos. A consciência, então, representaria uma quebra nesse processo de libertação, e até mesmo de criação artística (GUINSBURG e LEIRNER, 2008).

Sobre a poética surrealista, é possível destacar o desprendimento para com as regras gramaticais, com a ordem dos acontecimentos intrínsecos de determinada obra e com a lógica. O que verdadeiramente detinha um grau de significação para a vanguarda era o nível de abstração e de produção inconsciente gerada: 
- conceito clássico de "inspiração" desfez-se na revolução poética surrealista. [...] Os surrealistas procederam a uma reviravolta na escrita poética. Criar deixou de ser para eles um acto individual e intimista no mais refinado dos silêncios onde mora a metafísica. A metáfora benigna e verossímil do romantismo estilhaçou numa inverossimilhança sem precedentes diacrónicos. O poeta perde o tom melífluo e desenxabido de tempos idos e de gostos recessos. [...] $\mathrm{O}$ acto da criação seria pois mais do que um acto de recriação. Seria mesmo um pacto de agressão... Pelo que, a poesia enveredou por algumas experiências e práticas surrealistas da linguagem mediante processos de criação grupal, cujos "poemas" ficaram conhecidos como "cadavres exquis" (BRITO, 2005, p. 185- 186)

No reconhecimento do irracional e inconsciente como parte do fazer poético, a vanguarda quebra com a supremacia de um autor, um criador supremo, este, que passa a ser um receptor real da sua própria obra, visto que não há como controlar o que os seus companheiros de invenção expuseram, "sujeitando-se a um comprometimento com o vazio e com a espera" (BUENO, 2017, p. 80). A técnica do cadáver esquisito abre precedentes para o que os estudiosos e artistas da escola tanto buscavam: a mistura entre desejo e sonho, "algo entre a submissão do ego aos processos do inconsciente, em uma abertura para 0 desconhecido" (BUENO, 2017, p. 80), sendo o desconhecido, o outro. O objetivo é que, a partir de jogos e de criações produzidas ao acaso, novas possibilidades artísticas sejam conhecidas e desbravadas.

Concretamente, segundo o registro que faz Pianowski de autores referências no surrealismo, como André Breton e Tristan Tzara, a técnica surgiu em 1925, em uma casa onde o escritor se reunia com o pintor Yves Tanguy e os poetas Jacques Prévert e Benjamin Péret. O nome é resultado da primeira vez em que o jogo foi posto em prática quando surgiu a frase: "le cadavre exquis boira le vin nouveau", traduzida por "o cadáver esquisito beberá o vinho novo". Para Tristan Tzara, segundo registro de Pianowski, "a receita para o cadavre exquis escrito era: pegar uma folha de papel dobrada o número de vezes correspondente ao número de participantes, na qual cada um escreveria o que passava por sua cabeça sem ver o que tinham feito anteriormente seus companheiros" (PIANOWSKI, 2007, p. 2). Pianowski ainda diz, agora de acordo com Collinet, que "havia uma sequência rígida a ser respeitada: substantivoadjetivo/advérbio-verbo-substantivo, com o objetivo de obter o mínimo de coerência no resultado que ao final seria lido para todos, pois os resultados totalmente absurdos e incoerentes acabavam (...) parando no lixo" (PIANOWSKI, 2007, p. 3).

Desse modo, percebemos que a técnica não era feita de modo totalmente aleatório. Os jogadores/poetas se preocupavam com que uma estrutura mínima fosse respeitada a fim de produzir algo relevante ao cabo do processo, podendo ser um objeto artístico incompreendido no campo semântico, mas internamente submetido a uma linha lógica. Dada a relação do surrealismo com o inconsciente, pode-se pensar erroneamente que a poesia surrealista seria apenas uma reflexão do onírico, dos sonhos, como se ela não estabelecesse nenhuma relação com a realidade. No entanto, é a partir da subversão da realidade que os surrealistas se posicionavam e demonstravam seus desconfortos perante as problemáticas políticas e sociais dos seres humanos (CESARINY, 1997).

O cadáver esquisito também não era uma técnica que se resumia apenas à escrita, sendo utilizada em outras artes, como na produção de desenhos coletivos. Ainda segundo Tzara, citado em Pianowski (2007), o número indicado de participantes para a criação do desenho era de três e havia uma sequência a ser seguida: cabeça/tronco-pernas. Barroso (2014), ao estudar a produção de Mário Cesariny, por exemplo, não enfoca apenas no seu trabalho como poeta, mas especialmente no viés artístico do autor português, posicionando-o como um poeta da imagem e apontando a integração que ele foi capaz de fazer entre a literatura e as artes plásticas.

Em suma, o cadáver esquisito é uma técnica que proporciona ao artista uma fusão de combinações sígnicas e artísticas, ampliando as possibilidades de experimentação com o fazer estético tanto no plano individual quanto coletivo. No caso da poesia, dá uma 
dimensão diferenciada à associação de palavras em uma estrutura que desafia a criatividade do poeta e do leitor do poema.

\subsection{Letramento literário e poesia em sala de} aula

O arcabouço teórico que norteia a nossa prática vem do letramento literário e sua aplicação no ambiente escolar. Para Paulino e Cosson, a primeira condição para o letramento literário acontecer é o contato direto do leitor com o texto literário. Os autores também pontuam acerca da construção de uma comunidade de leitores a fim de torná-los indivíduos constituintes de um processo que "assegura a participação ativa do aluno na vida literária e, por meio dela, a sua condição de sujeito." (PAULINO; COSSON, 2009, p. 74). Dessa forma, o ensino de literatura tem como função, para além do exercício da leitura como fruição ou prazer,

nos ajudar a ler melhor, não apenas porque possibilita a criação do hábito de leitura ou porque seja prazerosa, mas, sim, e sobretudo, porque nos fornece, como nenhum outro tipo de leitura faz, os instrumentos necessários para conhecer e articular com proficiência $O$ mundo feito de linguagem. (COSSON, 2019 , p. 30, grifo nosso)

Entender as imbricações de um texto literário como linguagem requer manipular seus elementos de uma forma consciente. Por isso, adentrar em um universo permeado pelas palavras poéticas através de uma prática de letramento literário pode aproximar o aluno de métodos de criação que colocam a literatura não mais numa posição inalcançável, mas sim atraente, possível e passível de manuseio. Daí a importância de práticas de letramento literário na escola que tornem a leitura e a produção de textos literários uma atividade de compartilhamento (COSSON, 2019). Essa posição é reforçada por Hélder Pinheiro, para quem "a leitura do texto poético tem peculiaridades e carece de mais cuidados do que 0 texto em prosa". Até porque, como complementa o autor, "a poesia é, entre os gêneros literários, dos mais distantes da sala de aula, [logo] a tentativa de aproximá-la dos alunos deve ser feita de forma planejada" (PINHEIRO, 2018, p. 21)
Por isso, é essencial trabalhar com uma concepção de poesia que, antes de ser inspiração, dom, dádiva herdada de uma família de escritores, é linguagem. Nessa condição, o texto poético passa por técnicas, repetições e aperfeiçoamentos, oferecendo também várias possibilidades de interação, a exemplo das inúmeras sugestões feitas por Pinheiro (2018). A lição final é que "como um modo especial de linguagem, a poesia, através do jogo sonoro [...] e semântico, desloca sentidos, cria outros, revitaliza palavras através de associações inusitadas, joga com a tensão entre som e sentido" (PINHEIRO, 2018, p. 87).

Tendo em vista esses pressupostos e orientações, entendemos que a prática do cadáver esquisito possibilita que o aluno entre em contato com uma forma de produção e recepção poética significativa para a sua formação de leitor literário.

\section{Lendo "O vermelho e o verde" na sala de aula}

$\mathrm{Na}$ apropriação da proposta do cadáver esquisito dos surrealistas, seguimos vários passos para torná-la uma prática de letramento literário para trabalhar com poesia em sala de aula e subverter o senso comum em relação à escrita poética como inspiração. O primeiro desses passos foi a seleção de um texto surrealista para servir de motivação e modelo para os alunos. O texto literário escolhido foi o poema "O vermelho e o verde" de João Artur Silva e Mário Batista Henrique Leiria:

O VERMELHO E O VERDE

- De que cor é o vermelho?

- É verde.

- Quem é o teu pai?

- É o revisor do comboio para a lua.

- O que é a loucura?

- É um braço solitário sorrindo para os meninos.

- Quem é Deus?

- É um vendedor de gravatas.

- Como é a cara dele?

- É bicuda, com uma maçaneta na ponta.

(SILVA; LEIRIA, 1989, s/p) 
Esse poema consta da Antologia do cadáver esquisito (1989), organizado por Mário Cesariny, considerado o principal representante do surrealismo português. Como o poema tende a provocar interpretações bastante diversas, além de, possivelmente, uma ideia de pouco sentido ou incompreensão nos leitores, acreditamos que ele seria interessante para introduzir o fazer poético a partir da prática do cadáver esquisito.

Para iniciar nossa conversa, propomos ler o poema com os alunos a partir do ponto de vista de sua própria elaboração. Neste caso, não é possível saber se algo foi predeterminado para a criação do poema, mas a primeira observação é a de que ele é estruturado a partir de perguntas e respostas. Nossos questionamentos foram: será que as perguntas foram mostradas antes para serem respondidas ou 0 contrário?

Compreendemos que toda leitura literária acontece pela transação do leitor com o texto (ROSENBLATT, 1994), entretanto, acreditamos que no caso dos poemas surrealistas que usam a técnica do cadáver esquisito essa transação fica ainda mais evidente já que a elaboração dos poemas é fruto de um "quebra-cabeça" de palavras e frases montadas por mais de um autor. Dessa forma, a interpretação do poema "O vermelho e o verde" nos leva a uma análise dos processos constitutivos de produções surrealistas, que tratam do redirecionamento de sentidos e uma poética da abstração, em que a realidade se reverbera inusitadamente perante a criação artística.

Levando em consideração que o poema foi escrito sob o prisma do cadáver esquisito, é importante compreendermos minimamente o que há por trás da desautomatização da lógica. De acordo com Natália Correia:

não é de se admirar que ocorra frequentemente na poesia surrealista a técnica do enigma, surtindo o poema como uma proposta de decifração de coisas que se descrevem a partir de outras. Sendo a imagem poética uma degradação, mas também uma tentativa de recuperação da metáfora linguística, que na ordem mágica das sociedades primitivas encarna 0 princípio da parte pelo todo, e viceversa, regra de ouro da cosmovisão surrealista, é compreensível que o valor analógico da imagem seja objeto das pesquisas experimentais do surrealismo. (CORREIA, 2002, p. 351)

Ou seja, o enigma, que se faz presente no poema referenciado, traz consigo uma infinidade de resoluções outras, podendo expressar formulações irracionais, inexatas ou assimétricas, mas que metaforicamente podem convergir para um patamar estético e interpretativo, na concepção de Correia (2002), em que a poeticidade participa do constante jogo de degradação e recuperação.

É assim que o título do poema nos levou a buscar o significado das cores. De acordo com o site Dicionário de Símbolos (FUCKS, DIANA e FERNANDES, 2020), na cromoterapia, o vermelho é uma cor que estimula o sistema nervoso. Também é uma cor ambígua, pois há diferença entre as tonalidades dela, se for mais escura, representa a guerra e o perigo, sendo mais clara, representa o amor e a sorte. O primeiro verso do poema surge com a pergunta "De que cor é o vermelho?" Como podemos perguntar a cor de uma cor? Seria um outro grau de sinestesia? Não é só a busca pelo cheiro, pelo gosto de uma cor, mas por qual cor ela verdadeiramente é. Será que o vermelho pode ser, na verdade, uma outra cor? E vermelho será verde então? De acordo com a fonte já mencionada, o verde também representa sorte, com o vermelho. Seria essa uma imbricação das duas cores? Além de que, segundo a Física, as cores não existem realmente, o que é existe é a percepção da luz e ela não é construída pelos nossos olhos e, sim, pelos nossos cérebros, logo, a cor que eu vejo pode não ser a mesma que outra pessoa vê. Logo, sim, o vermelho pode ser verde.

Antes de apresentarmos os outros versos, é interessante frisarmos a própria estrutura do poema que remete a um diálogo, um jogo de perguntas e respostas e/ou um "bate boca". Provavelmente, ele foi construído assim, com as perguntas ou as respostas já dadas anteriormente para que o contrário fosse complementado. Olhando com os pressupostos da linguagem cotidiana, o poema parece não fazer sentido algum, mas é essa justamente a proposta dos 
surrealistas: construções feitas pelo acaso que resultam em um sentido inusitado e construído.

Outro ponto observado é a própria profundidade das perguntas, podemos considerá-las como existenciais, perguntas que muitos de nós fazemos durante a vida inteira e, às vezes, morremos sem respostas. De que cor é o vermelho? Quem é o teu pai? O que é a loucura? Quem é Deus? Como é a cara dele? Cada uma dessas perguntas envolve reflexões profundas e séculos de estudos de diversos ramos científicos. Já no poema, elas parecem ser respondidas com muita objetividade (e simplicidade?) com apenas um verso.

Temos no segundo bloco o diálogo "Quem é o teu pai?/ É o revisor do comboio para a lua." Em muitos lugares, saber de quem alguém é filho significa conhecer a origem e os antecedentes históricos de uma pessoa, sendo esta uma informação que pode vir antes de uma apresentação formal. A paternidade é um dos laços familiares mais fortes e que mais influenciam na construção do psicológico humano, no sentido de que o parentesco geralmente é o nosso primeiro contato com o mundo exterior, junto com a nossa mãe. Voltando ao poema, seguimos com "- É o revisor do comboio para a lua." Ou seja, o pai é aquele funcionário do trem que fiscaliza os bilhetes, o responsável para que a viagem ocorra bem. O detalhe está no destino: a lua. Longe de ser uma referência à primeira viagem do homem para a lua, que aconteceu apenas em 1969, o verso parece vir atrelado ao sentido de "lunático", pessoa ou situação associada ao irreal, a uma viagem inusitada e distante. Viver "no mundo da lua" pode significar um desprendimento lúdico para com a realidade. O pai, essa figura construída historicamente de forma tão séria, surge aqui como se fosse personagem de uma história infantil.

Em "O que é a loucura? / É um braço solitário sorrindo para os meninos", podemos refletir que representar a loucura através do riso é algo relativamente comum. No cinema, por exemplo, o desprendimento com a sanidade se verte em risada, em gargalhadas, muitas vezes, por parte daqueles considerados loucos. Mas é interessante pensar na própria pergunta: o que é loucura? A loucura de fato existe? Ou é tudo uma questão de percepção? A loucura, muitas vezes, foi e é utilizada como um pretexto para prender, isolar ou censurar grupos de pessoas que não concordavam com uma determinada ordem estabelecida ou que simplesmente eram considerados diferentes, como podemos observar através da história (ARBEX, 2013).

O próximo verso do poema vem com talvez uma das perguntas que mais causam questionamentos ao longo da história da humanidade ocidental: quem é Deus? Sendo a resposta: "É um vendedor de gravatas". Pensamos na simplicidade da resposta e na profundidade abarcada por ela. Deus pode ser mesmo um vendedor de gravatas, afinal, há como definir quem Ele é? O que Ele é? Ele realmente existe? A reflexão que fazemos é da infinidade de respostas para essa pergunta, por que não ser Ele um vendedor de gravatas? Segundo a doutrina cristã, Jesus, uma das faces de Deus, veio para a Terra como alguém simples, um ser humano comum, que se juntou aos pobres, aos enfermos, aos considerados sem valor para ensinar à humanidade sobre o verdadeiro significado da vida. Logo, ele certamente não seria um empresário, um rico, um explorador, mas, não estaria excluída simbolicamente o simples vendedor de gravatas.

O último bloco de versos "Como é a cara dele? / É bicuda, com uma maçaneta na ponta." É o único que pode ser ligado à pergunta anterior, a que questiona quem é Deus. Nesse caso, a resposta é que ela é bicuda. Em nosso imaginário, um rosto bicudo é a cara de alguém antipático, alguém ranzinza, mas, em uma outra angulação, o fato dela ser bicuda nos sugere longuidão. Imaginemos um bico. Inicia bojudo e termina fino. Ou seja, resultaria em um rosto extenso, com um formato que finaliza em um ponto. Será o ponto a humanidade? Todas as coisas? Este ponto nos busca? Será Deus assim? Adiante, temos: "com uma maçaneta na ponta". A partir desse prisma, é possível subentender que a divindade, não sabemos se cristã ou não, simboliza acesso. Entendendo que assim o poema se esvai, a reflexão de que talvez todo o processo de desbravar os sentidos do texto 
representa uma porta aberta, não fica tão distante assim. A cada pergunta que se passa, um enigma é destravado e uma porta se abre.

Selecionado o texto literário, partimos para as atividades da prática. Quando reunimos os alunos na aula, enviamos o poema "O vermelho e verde" para a turma, tanto no chat quanto no grupo de whatsapp e pedimos que, em cerca de 10 minutos, cada um escrevesse individualmente suas impressões sobre o poema, fazendo uma breve análise do mesmo. Logo após esse momento, disponibilizamos para a turma assistir na plataforma Youtube um videopoema ${ }^{1}$ criado por nós a partir de "O vermelho e o verde" no intuito de discutir sobre uma possibilidade de reprodução interartística do que estava escrito por meio de uma performance. De acordo com Zumthor (2010):

performance implica competência. Além de um saber-fazer e de um saberdizer, a performance manifesta um saber-ser no tempo e no espaço. O que quer que, por meios linguísticos, o texto dito ou cantado evoque, a performance Ihe impõe um referente global que é da ordem do corpo. É pelo corpo que nós somos tempo e lugar: a voz proclama, emanação do nosso ser. [...] E por isso que a performance é também instância de simbolização: de integração de nossa relatividade corporal na harmonia cósmica significada pela voz; de integração da multiplicidade das trocas semânticas na unicidade de uma presença. (ZUMTHOR, 2010, p. 166, grifos nossos):

Ou seja, um texto performado recebe uma estrutura que o vivifica através da atribuição de sentido por meio de dispositivos orgânicos: corpo e voz. Isso possibilita uma infinidade de permutas semânticas na posição de quem expõe e de quem recebe. Um verso, por simples que seja, pode ter o seu significado afetado de acordo com as relações que o performer e o receptor estabelecem entre as modulações vocais e os movimentos, gestos ou manipulação de objetos no cenário construído pelo primeiro. Tais percepções, quando inseridas em debates literários, podem suscitar leituras de caráter sinestésico e até mesmo associações com ambientes próximos ao cotidiano dos educandos, já que plataformas audiovisuais estão em evidência e vêm ganhando o predomínio da atenção de uma parcela considerável dos jovens, a exemplo do YouTube e da Netflix. No entanto, é necessário frisar que, inicialmente, o poema seria lido em voz alta, presencialmente, o que não minimiza as conexões que fizemos durante a seleção do texto.

Sobre a produção do videopoema, é importante destacarmos a forma como foi pensado e executado. A produção audiovisual foi feita às cegas, ou seja, nós não combinamos e nem pensamos em nenhum direcionamento específico, apenas dividimos as partes do poema. A decisão se deu tanto pelo fato de estarmos em isolamento social em decorrência da pandemia da Covid19, quanto pela possibilidade de realizarmos um cadáver esquisito em formato audiovisual. Uma das autoras ficou com as perguntas e outra com as respostas.

Em um segundo momento da aula, partimos para a análise conjunta do poema com a turma, utilizando também o vídeo como base para a construção da interpretação. Discutimos cada parte do poema, gerando um debate acerca das primeiras impressões e das significações que contemplam determinadas palavras. Depois da discussão, pedimos para que cada um revisse e registrasse novamente suas impressões acerca do poema. O momento está alicerçado no processo de letramento literário trazido por Cosson:

discutir em sala de aula implica que os alunos falem uns para os outros, que exponham a sua posição sobre 0 assunto e ouçam a posição do outro, que interajam entre si e com o professor. [...] trata-se de um debate autêntico, em que os alunos dividem dúvidas e certezas, usam as informações do texto para construir argumentos, questionam o texto com base em suas experiências e dialogam entre si tanto quanto com o professor. (COSSON, 2019, p.126)

Ou seja, a etapa de discussão não é desenvolvida de forma aleatória, mas estrategicamente planejada para desencadear uma

\footnotetext{
${ }^{1}$ Disponível em

https://www.youtube.com/watch?v=rHjqnWRnoVU\&fe ature=youtu.be. Acesso em: 10 out. 2020.
} 
série de posicionamentos e ligações que dialoguem com o histórico de leitores, com experiências ou percepções que surjam no momento do compartilhamento com os demais colegas.

O próximo passo foi dividir a turma em grupos, no nosso caso, a distribuição se deu com quatro grupos de cinco pessoas. Como o processo foi virtual, necessitamos da colaboração de duas colegas para administrar dois dos grupos. Cada grupo recebeu uma palavra, sendo elas: toca, trem, rosa e boca. Foi solicitado que cada um escrevesse um verso contendo a palavra-chave escolhida para o grupo. Ao término da produção, o colega enviou o verso para o administrador do grupo, no modo privado. O coordenador, então, uniu aqueles quatro versos e formou um poema. Portanto, cada grupo criou um poema.

A escolha dessas quatro palavras não foi aleatória, antes, buscamos aquelas que pudessem expressar múltiplos significados, a fim de que 0 resultado dos versos de cada poema não tendesse ao monotemático. Fizemos uso de um outro dicionário de símbolos (CHEVALIER e GHEERBRAN, 2019) para selecioná-las. Disponibilizamos cerca de 15 minutos para o momento de criação. Se estivéssemos em um formato presencial, distribuiríamos folhas de papel ofício para os grupos, e pediríamos que o primeiro dobrasse a folha como um leque correspondente ao número de participantes. Cada um escreveria o verso e passaria para o colega da direita até que todos tivessem escrito frases nos papéis. Ao final, teríamos um poema feito em conjunto. $O$ ensino presencial também possibilitaria um maior número de alunos por grupo, não sendo necessário um coordenador para recolher e organizar os versos. Entretanto, fizemos as adaptações necessárias e foi possível realizar a prática em meio virtual.

Ao final de cada produção, o coordenador de cada equipe leu o poema em voz alta. Por fim, realizamos um último momento de compartilhamento pedindo que todos falassem sobre o que acharam desse processo de criação, proporcionando um momento de avaliação do que foi vivenciado.

\subsection{Os resultados da leitura}

$\mathrm{Na}$ visualização do videopoema e da exposição sobre as primeiras impressões acerca dos versos, os colegas ficaram surpresos com o vídeo produzido e realizaram uma série de indagações sobre como ele foi feito, se estávamos nos olhando virtualmente, se as reações foram roteirizadas, combinadas. Uma aluna elaborou uma relação entre as cores da poesia e o lenço utilizado na performance audiovisual, revelando, que foi possível, por parte dos colegas, estabelecer interpretações e ligações entre a performance e a obra escrita.

O momento de análise conjunta do poema com a turma foi inteiramente espontâneo, com quase todos os alunos compartilhando seus olhares sobre 0 poema. Esse compartilhamento foi essencial para que todos entendessem de fato que a interpretação de um poema feito a partir da técnica do Cadáver Esquisito provoca diversas interpretações porque estas estão relacionadas intrinsecamente com o repertório sociocultural do leitor, suas crenças, seus sentimentos, sua personalidade.

Essa etapa nos levou a refletir sobre como o ensino de literatura pode, na prática, ampliar a competência literária dos alunos. Como já relatamos, o poema é de difícil análise, por causar dúvidas quanto à forma de produção, aos sentidos e até mesmo aos costumes da época que foi produzido. Todos esses questionamentos também foram ressaltados no momento de discussão, resultando em ganhos interpretativos relevantes.

As interpretações feitas ampliaram a análise inicial do poema e fez com que percebêssemos nuances que não havíamos pensado antecipadamente, como a relação das respostas inusitadas do poema com o imaginário infantil. "Poderia ter sido escrito por uma criança", um dos colegas declarou. Foi possível explorar cada um dos versos de maneira profunda, bem como relacioná-los ao videopoema e à poesia surrealista como um todo. Se dependesse da turma, pelo que percebemos, a conversa sobre cada um dos versos do poema poderia se estender por toda a tarde, por isso, foi necessária 
uma intervenção mais acentuada para encerrar as discussões.

Na última etapa da prática, após dividirmos os grupos e explicarmos como os poemas seriam feitos, aguardamos cerca de 15 minutos para a produção dos versos. O Grupo 1, que ficou com a palavra "boca", produziu o seguinte poema:

\section{BOCA}

Da boca as sutilezas do pensar A boca grita os sussurros da mente A boca do coração fala de boca cheia?

O que a boca não se atreve a dizer, a mão tece e os olhos revelam

\section{Autoria: Grupo 1}

É possível perceber que parte do poema diz respeito ao que a palavra "boca" representa no tocante à força do pensamento, em seu sentido de expurgar ideias, como em "Da boca as sutilezas do pensar" e "A boca grita os sussurros da mente". Nos dois últimos versos, temos metáforas que jogam com o sentido do uso da boca para pronúncias. Com "A boca do coração fala de boca cheia?", podemos associar o questionamento aos exageros que podem perpassar 0 coração humano, seja nas suas escolhas, nos seus atos, nos seus posicionamentos. Em seguida, o poema é finalizado com o silêncio a que a boca pode ser submetida ou optar por não dizer. O corpo é veículo dos nossos sentimentos e reações, logo, mesmo que uma pessoa não exponha verbalmente o que ela tem a dizer, o corpo se encarregará de "entregar". A produção dos colegas revela bocas e falas que refletem multiplicidade e força.

O Grupo 2 teve a palavra "trem" como a fonte de inspiração para a criação de sua poesia e, ao unirmos os versos, obtivemos este poema:

\section{TREM}

Sai dos trilhos, doida, entra no trem

Corre na velocidade dos rios

Há no trem, um trem que não entendo: qual frente vai, qual frente vem

Vai longe perto da minha sombra... $\mathrm{O}$ trem descontrolado em minha direção..

Autoria: Grupo 2
O poema é permeado de imagens e referências oníricas. A simbologia da palavra trem sugere uma infinidade de associações. Ao ler a produção, é possível delinear uma sequência de acontecimentos e sentidos que se entrelaçam, apesar de tão distintos. A construção imagética do trem vindo em nossa direção é algo que frequentemente surge em nosso imaginário. Indagações do tipo: o que eu faria? E se eu estivesse preso? Quando visualizamos um trem que "corre na velocidade dos rios", podemos associar ao tempo que inunda nossa existência. A vida pode mesmo ser esse trem que não entendemos "qual frente vai, qual frente vem" e se distancia e depois se aproxima "[...] descontrolado em minha direção". Mesmo não havendo diálogo entre os autores, é possível perceber um contínuo, como um comboio que flui.

Com o Grupo 3, a palavra foi "rosa" e unidos os versos criados formou-se esse poema:

ROSA

A rosa não é mais rosa

É a amizade entre sentinelas malvados É preciso que haja uma rosa para desabrochar

Rosa-mirim: do teu furo corte te dou sangue

Rosa gelo desbotada disseram que bonita nada além disso

Autoria: Grupo 3

O sentido da palavra rosa é vasculhado e perseguido nos versos do poema. A persistência da rosa como uma planta é reforçada, sem entrar no monotemático: uma rosa que não é mais uma rosa em sua essência ou que não possui tal coloração, talvez por ferir, por servir de instrumento malfeitor. No entanto, sua necessidade é assegurada no próximo verso, "é preciso que haja uma rosa para desabrochar". O novo sempre vem e é preciso compartilhar com ele a sua essência, seu sangue, como em "Rosa-mirim: do teu furo corte te dou sangue". Trocar feridas, cores vermelhas, se encarnada a rosa for. A rosa pode ser tudo isso e nada disso: apenas bonita. 
Por fim, o Grupo 4 recebeu a palavra "toca" para criar seus versos. Este foi o resultado da união dos versos produzidos pelos integrantes do grupo:

\section{TOCA}

Um galho toca em minha janela e desperto no meio da noite A saudade daquele beijo me toca Existem portas que nunca serão tocadas e se abrem para sempre, nunca serão fechadas Um recanto pra guardar a culpa No caos da pandemia, na toca, não sabia o que desejava.

Autoria: Grupo 4

Uma das palavras com mais abertura de significados, a palavra toca se transforma, sente fisicamente e emocionalmente as dores e amores do eu-lírico. Em cada um dos verbos, a palavra toca tem seus múltiplos significados explorados, no primeiro, temos o verbo "tocar" no sentido de encostar, de "bater". É interessante perceber como o primeiro verso se interliga com o sentido, demonstrando o que o eulírico pode ter acordado não só pela batida do galho, mas também pela saudade de um beijo e esse toque do beijo pode ser não só físico, mas sendo o "tocar" da memória, o tocar que emociona. Toca porque afeta. No terceiro verso, temos também o sentido metafórico de portas, podendo ser lidas como portas de sentimentos, de sensações que podem nunca serem sentidas novamente - ou pela primeira vez - e que, por isso mesmo, nunca se fecharão, permanecerão sempre abertas imbuídas de saudade nesse recanto que é também uma toca, um esconderijo, para guardar sentimentos ou para senti-los em solidão. Esse lugar que pode ser físico ou metafórico, o quarto ou o coração ou a boca, mas que nesse caos da pandemia se torna mais latente.

No processo de junção dos versos produzidos, a colega que coordenou o Grupo 1 (boca) foi a única dentre os administradores que não escolheu a ordem dos versos, apenas os juntou na ordem que recebeu no modo privado do aplicativo WhatsApp. Os outros administradores buscaram uma organização que rendesse um sentido maior ao todo. interessante é que, em nossa conversa posterior, após lermos os poemas construídos para a turma, percebemos que não havia diferença na coerência dos poemas, nem o "montado" pela coordenadora do Grupo 1, nem das três demais equipes, que haviam alterado a ordem enviada, comprovando que aquilo que dá a coesão para as poesias criadas nessa técnica não é sua estrutura externa, mas os sentidos criados internamente pelos versos.

O momento da realização da atividade e discussão sobre os resultados também foi bastante satisfatório para nós porque pudemos ver na prática como a técnica do cadáver esquisito funciona. Antes de realizarmos tal prática, apenas com as leituras que fizemos e por nunca termos feito com alunos, não fazíamos ideia se ela funcionaria tão bem como é descrito pelos autores que a estudam.

A impressão sentida é que o universo dos sonhos, da fantasia, da subversão realmente se mistura com a realidade e "de repente" nos tornamos poetas. É importante destacar a dupla dificuldade, tanto por nunca termos aplicado a prática, quanto por estarmos lidando com um outro formato, o virtual. Em decorrência à pandemia da Covid-19, muitas das etapas que havíamos planejado foram adaptadas, o que causou uma insegurança no que diz respeito aos rumos que o momento poderia tomar. Felizmente, as impressões finais, bem como a recepção da turma foram as melhores.

Não só nós nos surpreendemos, como também a turma com os poemas criados, e foi interessante 0 instante de conversar sobre a possibilidade de realizarmos tal prática com nossos alunos em sala de aula, como um meio de aproximar crianças e adolescentes da poesia, como é proposto por Fábio Andrade (2013). Durante a conversa com a turma sobre a técnica do cadáver esquisito foi possível desconstruir algumas noções equivocadas de que a criação dos poemas surrealistas é feita de maneira "aleatória" ou sem nenhuma coesão e que, sim, como toda técnica é feita a partir de regras internas estabelecidas pelos participantes desse "jogo". Além disso, a forma de levarmos a turma a escrever poemas, por intermédio dessa prática, nos revela e comprova que jogar com a linguagem poética é fundamental, por isso cabe a nós, professores de 
literatura, reforçarmos esse caráter de jogo da poesia que é contrário ao texto poético como algo distante, abstrato e difícil. Não só a poesia, mas a produção artística em si, não deve ser associada à inspiração e ao dom. Arte também é prática, técnica e jogo. Os resultados obtidos mostram isso com clareza.

\section{Considerações finais}

Optamos por trabalhar com a poesia porque acreditamos que ela é necessária em sala de aula e que, apesar de esforços diversos dos professores, ela ainda é pouco difundida em sala de aula de maneira a promover uma experiência literária. Sabemos que, nos livros didáticos, muitas vezes, a poesia ainda é usada como pretexto para estudar classes gramaticais ou apenas para os alunos aprenderem aspectos formais - como métrica, rima, escansão. Isso afasta as crianças e jovens da poesia - e da literatura como um todo - e os fazem crer que poesia é algo difícil, inacessível ou simplesmente aborrecido. Por isso, escolhemos realizar tal prática.

A técnica do Cadáver Esquisito, desenvolvida pelos surrealistas, brinca com a linguagem poética, com a língua, com a ideia de inspiração e até mesmo com a lógica com a qual costumamos construir sentidos. Sendo assim, acreditamos que ela pode ser um meio de aproximar aqueles que a experimentam do fazer poético. E, claro, que isso só acontece através de planejamento, com escolhas pensadas no intuito de atingir um objetivo bastante definido.

Com os poemas criados, nossas expectativas foram superadas e as da turma também, e, assim, atestamos que criar poemas a partir da prática do Cadáver Esquisito é possível e pode ser uma potencial ferramenta de aproximar crianças e jovens da poesia, demonstrando que criar poemas pode ser algo divertido e fluido, uma experimentação estética. Todos os poemas produzidos pelos alunos possibilitam diversas interpretações e ampliaram aquilo que a turma e também nós acreditávamos sobre fazer poesia.

\section{REFERÊNCIAS}

ANDRADE, F. Oficina de criação poética: uma prática pedagógica para o ensino de literatura. Revista Encontros de vista: Edição JAN / JUN - 2013. Disponível em: <http://www.encontrosdevista.com.br/Artigos/artigo_4 _11.pdf> Acesso em: 15 ago. 2020.

ARBEX, D. Holocausto brasileiro 1. ed. - São Paulo: Geração Editorial, 2013.

ARTUR SILVA, J.; BAPTISTA LEIRIA, M. O vermelho e o verde. In: Antologia do cadáver esquisito. Org: Mário Cesariny. Lisboa: Assírio \& Alvim, 1989.

BRITO, F. Cadavre exquis. Revista da Faculdade de Letras - Línguas e Literaturas, II Série, vol. XXII, Porto, 2005, pp. 185-188. Disponível em: $<$ https://repositorio-

aberto.up.pt/bitstream/10216/8693/2/4732.pdf> Acesso em: 23 abr. 2020

BUENO, D. Aproximações do cadáver esquisito à performance. elyra: Revista da Rede Internacional Lyracompoetics, n. 10, 16 jan. 2018, pp. 79-89. Disponível em: <https://www.elyra.org/index.php/elyra/article/view/20 5/251 $\geq$ Acesso em: 23 abr. 2020.

CESARINY, M. A invenção surrealista. Lisboa: Assírio \& Alvim, 1997.

CORDEIRO, A. Gramática da fantasia: o surrealismo nas aulas de produção de texto. In: SIMPÓSIO INTERNACIONAL DO ADOLESCENTE, 2., 2005, São Paulo. Anais eletrônicos... Disponível em: $<$ http://www.proceedings.scielo.br/scielo.php?script=s ci_arttext\&pid=MSC0000000082005000200020\&lng= en\&nrm=abn>. Acesso em: 23 abr. 2020.

CORREIA, N. O Surrealismo na Poesia Portuguesa. Lisboa: Frenesi, 2002.

COSSON, R. Círculos de leitura e letramento literário. São Paulo: Contexto, 2019.

FUKS, R; DIANA, D.; FERNANDES, M. (Eds). Vermelho - Dicionário de Símbolos. 7Graus Lda, 2020. Disponível em: <https://www.dicionariodesimbolos.com.br/vermelho/> . Acesso em: 18 abr. 2020.

GUINSBURG, J.; LEIRNER, S. (Org.) O Surrealismo. São Paulo: Perspectiva, 2008.

PAULINO, G.; COSSON, R. Letramento literário: para viver a literatura dentro e fora da escola. In: Org: Regina Zilberman e Tania Rosing. Escola e literatura: velha crise, novas alternativas. São Paulo: Global, 2009.

PAZ BARROSO, E. (2014). Pintura e poesia experimental: Ambientes e contextos na segunda metade do século XX português. In: TORRES, R. (Org.). Poesia Experimental Portuguesa: Contextos, 
Ensaios, Entrevistas, Metodologias. Porto: Edições UFP, p. 32-47. ISBN 978-989-643-121-1. Disponível em: <https://poex.net/taxonomia/transtextualidades/metatextualidade s-alografas/poesia-experimental-portuguesacontextos-ensaios-entrevistas-metodologias > . Acesso em: 13 set. 2020 .

PIANOWSKI, F. Construção do imaginário surrealista através do jogo cadavre exquis. In: Psikeba: revista de psicoanálisis y estúdios culturales, v. 1, ano $2-\mathrm{n}^{\circ} \mathrm{0}$, $2007 . \quad$ Disponível em: $<$ https://dialnet.unirioja.es/servlet/articulo?codigo=234 6401>. Acesso em: 15 jul. 2020.

PINHEIRO, H. Poesia na sala de aula. São Paulo: Parábola, 2018.

PLOMP, T.; NIEVEEN, N. (Eds.). Educational design research. Enschede, The Netherlands: SLO, 2013. Disponível em: <https://ris.utwente.nl/ws/portalfiles/portal/14472302/l ntroduction_20to_20education_20design_20research. pdf $>_{-}$Acesso em: 15 jan. 2020.

ROSENBLATT, L. The reader, the text, the poem: the transactional theory of the literary work. Southern Illinois University, 1994.

SEEL, N.M. Design Experiments. In: SEEL, N.M. (ed.) Encyclopedia of the Sciences of Learning. Springer, Boston, MA, 2012. Acesso em: 15 jan. 2020. https://doi.org/10.1007/978-1-4419-1428-6_913

ZUMTHOR, P. Introdução à poesia oral. Belo Horizonte: Editora UFMG, 2010.

ALMEIDA, Beatriz Pereira; OLIVEIRA CORDEIRO, Alinne de Morais; COSSON, Rildo. Ler e escrever criativamente: cores poéticas na prática de letramento literário cadáver esquisito. Signo, Santa Cruz do Sul, v. 46, n. 85, p. 227-238, jan. 2021. ISSN 1982-2014. Disponível em: <https://online.unisc.br/seer/index.php/signo/article/view/15819 doi:https://doi.org/10.17058/signo.v46i85.15819. 